\title{
Drugi hrvatski kongres o ruralnom turizmu s međunarodnim sudjelovanjem "Koncepcija dugoročnog razvoja ruralnog turizma", Mali Lošinj, Hrvatska, 21.-25. 04. 2010.
}

Ruralni turizam jedan je od najprepoznatljivijih posebnih oblika turizma, čija važnost je, prije svega, u interakciji poljoprivredne proizvodnje, potom one tradicionalnih proizvoda, prezentiranja tradicije, tradicijske gastronomije i turističkih usluga, odnosno u korištenju već postojećih resursa. Posebno je važno što se ruralni turizam temelji na održivom razvoju, koji se očituje u revitalizaciji već postojeće, tradicijske gradnje, odnosno baštine, kojoj se daje nova namjena - turistička. S obzirom na brojne probleme s kojima se u procesu razvoja ruralnog turizma susreću svi njegovi dionici, ukazala se potreba organiziranja Prvog hrvatskog kongresa o ruralnom turizmu. On je održan na Hvaru u listopadu 2007. godine i na njemu su, sa znanstvene i stručne strane, sagledane su sve dotadašnje aktivnosti koje su se odnosile na ruralni turizam, detektirane su poteškoće i postavljeni su novi izazovi kroz konkretne provedbene zaključke, te je, na taj način, ponuđen odgovarajući početni okvir za njegov daljnji razvoj. Zaključci Prvoga Kongresa doprinijeli su rješavanju različitih pretpostavki razvoja ruralnog turizma i potaknuli su suradnju na različitim razinama. Primjerice, donesena je "Deklaracija o ruralnom turizmu", potaknule su se aktivnosti rada Hrvatskog sabora i njegovih odgovarajućih odbora, što je rezultiralo održavanjem tematske sjednice "Aktualno stanje, mogućnosti i pretpostavke razvoja ruralnog turizma u Republici Hrvatskoj sa smjernicama njegovog razvoja”, intenzivirala se suradnja s resorima turizma, poljoprivrede, regionalnog razvoja, kulture, gospodarstva, jedinicama lokalne i regionalne samouprave, kao i različitim institucijama, u svrhu postizanja konačnog cilja - izrade "Strategije razvoja ruralnog turizma".

U Malom Lošinju, od 21. do 25. travnja 2010. godine, održan je Drugi hrvatski kongres o ruralnom turizmu s međunarodnim sudjelovanjem, "Koncepcija dugoročnog razvoja ruralnog turizma", u organizaciji "Hrvatskog farmera" d.d., Kluba članova "Selo" i "Ruralisa - konzorcija agroturizma i ruralnog turizma Istre". Okupio je 300-tinjak sudionika iz Hrvatske, zemalja iz regije i onih europskih, a u njegovu organizaciju bili su uključeni i europski stručnjaci i institucije. Rad Kongresa bio je organiziran u četiri tematske cjeline, kojima su prethodila uvodna predavanja. Uz to, održan je debatni klub i okrugli stol, a sve to pratila su brojna dodatna događanja kao što je, primjerice, predstavljanje primjera dobre prakse iz cijele Hrvatske i zemalja sudionica, gastronomije, tradicije, narodnih običaja, i drugo. 
U Uvodnim predavanjima bilo je riječi o aktualnom okruženju koje utječe na promišljanje dugoročnog razvoja hrvatskog turizma, pa tako i ruralnog, te se upozorilo da u "pripremama iduće turističke sezone" ruralni turizam ima tek sporadično mjesto, što raspravu o tome kakav ruralni turizam želimo u razdoblju između 2030. i 2040. godine čini bespredmetnom. Potom, predstavljeno je stanje ruralnog turizma u Hrvatskoj od Prvog hrvatskog kongresa o ruralnom turizmu održanog u Hvaru u listopadu 2007. godine do danas, s naglaskom na sveobuhvatnijem iskorištavanju pretpostavki razvoja ruralnog turizma, važnosti i nužnosti izrade, a potom i provedbe, odgovarajuće strategije njegovog razvoja, koja treba obuhvatiti postojeći značajni i bogati resursni temelj kao i sve aktivnosti vezane za održivi razvoj ruralnog prostora. Pozornost je posvećena i djelovanju ECOVAST-a, Europskog vijeća za sela i male gradove, u ruralnom turizmu, a posebno zanimanje pobudilo je predavanje naziva "Imamo li agroturizam kakvog smo zamišljali?”, koje je propitivalo održivost današnjeg shvaćanja, odnosno razvoja agroturizma u smislu njegovog daljnjeg opstanka i djelovanja u skladu s prijašnjim promišljanjima. Istaknuto je da je opstanak agroturizma, kao originalnog načina turističke ponude prema načelima stila života upitan i da je nužan radikalni zaokret. Ne bude li se on dogodio u cilju odvajanja agroturizma kao ponude koja nudi stil života domaćina (očuvanu tradiciju prilagođenu suvremenim uvjetima), oživljavanja poljoprivrede i pomaganja konkretnim potporama, prijeti mu nestanak.

Usprkos 25 milijuna kuna poticaja, 1500 subvencioniranih projekata i 100-tinu povoljnih kreditnih linija, domaći ruralni turizam nalazi se tamo gdje je austrijski bio prije 30-ak godina. Samo udruženim snagama ministarstava poljoprivrede i turizma mogući su veći pomaci u državnoj potpori ovoj vrlo atraktivnoj ponudi. Treba izdvojiti da je naglašeno kako je pogreška što je ruralni turizam razvijan kao izletišni, jer je postavljena mjera kapaciteta od 50 mjesta koliko ima autobus, pa sada od 360 registriranih agroturističkih imanja njih samo 50-ak ima sva obilježja toga oblika ponude. Premda zamišljen kao zajednički projekt poljoprivredne i turističke djelatnosti, agroturizam je pretvoren u čisti ugostiteljski posao, jer poljoprivreda nije uspjela održati korak i ostvariti zadovoljavajući prihod. Naglasak je ostao na tradicionalnoj poljoprivrednoj proizvodnji, ali u velikim serijama umjesto manufakturne kakvu imaju, primjerice, Provansa, Austrija i Španjolska. Najveći je problem što je izostalo predstavljanje agroturizma kao autentičnog životnog stila domaćina i što se on pretvorio u čisti biznis. Hrvatski agroturizam nudi turistički proizvod koji je emocionalno obojen i to je njegova osnovna karakteristika koju treba održati pod svaku cijenu. S tim u svezi izneseno je mišljenje da se treba vratiti 20-ak godina unatrag i ispraviti pogreške, dajući naglasak životnom stilu obitelji koja nudi uslugu, a ne podilaziti navikama gostiju, jer se tako poništava osnovni motiv za dolazak na selo. Greške su se dogodile i zbog zakonskih okvira, ali i ekonomskih uvjeta poslovanja, pa bi se morale ispravljati tako da se uvedu porezna rasterećenja obiteljima koje se bave agroturizmom. Treba uskladiti smještajne kapacitete s mogućnostima seoskog gospodarstva i osmisliti strukturne potpore. Ne učini li se to, od agroturizma će ostati samo naziv, kako je zaključeno u uvodnom promišljanju. 
S obzirom da 48\% stanovnika Hrvatske živi u ruralnim područjima, neoprostiv je izostanak razvojnih programa, nekorištenje projekata Europske Unije, nepostojanje prostornih planova na lokalnoj razini i nevladinih organizacija koje bi prepoznale kulturološki aspekt razvoja ruralnog turizma.

Osim navedenoga, Uvodna predavanja sadržavala su i prezentacije predstavnika europskih institucija, važnih i aktivnih u ruralnom turizmu, kao što su "Urlaub am Bauernhof", "Gites de France", "Accueil Paysan", "Rural Tourism International - RTI", i drugih. U njima bilo je riječi o tržišnim trendovima i trendovima gostiju u ruralnom turizmu Europe, marketinškim strategijama, onima razvoja proizvoda, iskustvima, sustavu treninga i edukacije u ruralnom turizmu, i drugo, što je vrlo poticajno za promišljanje i eventualnu "prerađenu" primjenu u ruralnom turizmu u Hrvatskoj.

Četiri tematske cjeline koje su usredotočile, predstavile i pokušale raspraviti brojne segmente, aktivnosti, probleme, i ostalo aktualno što se tiče ruralnog turizma i njegovih posebnih oblika, bile su raspoređene u dva radna dana Kongresa. Tematska cjelina "Ruralni prostor kao ruralna turistička destinacija" "brojila" je najveći broj radova i njihovih izlagača, gotovo 40, i obuhvatila je lepezu tema, problema, studija slučaja, primjera dobre prakse, analiza, novih istraživanja u ruralnom turizmu Hrvatske i zemalja u regiji. Obrađene slijedom opće prihvaćene metodologije, ozbiljno i pažljivo, argumentirano, znalački i stručno, ove teme dale su novi, dodatni doprinos razumijevanju prilika u ruralnom turizmu, još jednom potvrdivši širinu koju ruralni turizam u svom razvoju zahvaća.

Gastronomiji i ekološkoj proizvodnji hrane bila je posvećena tematska cjelina "Uloga hrane u razvoju ruralnog turizma", u okviru koje je predstavljeno 16 radova. U njima je, između ostaloga, istaknuta važna uloga hrane u ruralnom turizmu, potkrijepljena konkretnim primjerima i podacima. Razvidno je da potrošači sve više postaju ekološki osviješteni i da su spremni po višoj cijeni kupovati ekološki proizvedene proizvode. Prema provedenim anketama, većina turista koji dolaze u ruralna područja u Hrvatskoj spremni su platiti 15 do $20 \%$ skuplje namirnice i proizvode ako su ovi uzgojeni na ekološki način. Uz to, izdvojeno je da je prednost Hrvatske i u tome što ima mnogo nezagađenog tla, glavnog temelja ekološkog uzgoja, te da Hrvatsku pojedini turisti biraju isključivo zbog dobre hrane. Tako su neki proizvodi, primjerice tartufi, osim što predstavljaju vrhunac istarskoga kulinarstva, zanimljivi i u promidžbi zemlje, dok jačanje gastronomske ponude pridonosi i povećanju broja turista.

"Turistički multisektorski klasteri u ruralnom prostoru", tematska je cjelina u kojoj je raspravljano o klasterima, njihovom razvoju, poduzetništvu, uslugama i ostalom vezanom za oblike organizacije ruralnog turizma u Hrvatskoj i BiH. Važnost, i nužnost, marketinga i brendiranja ruralnog turizma obrađena je teorijskim izlaganjima i obradom primjera dobre prakse uglavnom iz Hrvatske u tematskoj cjelini "Marketing i brendiranje ruralnog turizma", u kojoj je bilo predstavljeno 13 radova. Zaključak je ove tematske cjeline da je potrebno iskoristiti sadašnji trenutak, usmje- 
riti oglašavanje na ciljano tržište, učiti od iskusnih, kopirati dobra rješenja i uzeti najbolje od internetskih društvenih mreža.

Svi radovi predstavljeni u spomenutim tematskim cjelinama, osim što su dostupni na CD-u, tiskani su na hrvatskom jeziku u integralnom obliku u dvosveščanom "Zborniku radova", koji broji 700-tinjak stranica. Time je hrvatska znanstvena javnost dobila vrijednu zbirku tekstova koji raspravljaju i obrađuju aktualnu situaciju u ruralnom turizmu, poglavito Hrvatske, koji tek od nedavno počinje dobivati primjerenu pozornost i kroz znanstvene i stručne radove/članke.

I dok su sve tematske cjeline bile "pokrivene" respektabilnim brojem raznovrsnih kvalitetnih radova, koje odlikuje profesionalnost, stručnost, znanstvena utemeljenost $\mathrm{i}$, nadasve, aktualnost i zanimljivost, nesrazmjerno je bilo malo vremena u kojem su predavači imali priliku predstaviti ih na odgovarajući način. Također, množila se i količina pitanja koje su teme "otvarale", no ni za rasprave nije bilo dovoljno vremena, što se može ubilježiti kao nedostatak, manjkavost Kongresa, jer šteta je da nije bilo odgovarajućeg vremenskog prostora i mogućnosti za diskusije. Uz to, u jednom danu na programu su bile tri tematske cjeline, dvije su se održavale kao paralelne sesije, a treća se djelomično preklapala s okruglim stolom koji je raspravljao aktualnu temu koja se odnosila na osmišljavanje "Strategije razvoja ruralnog turizma", čime se onemogućilo prisustvovanje cjelokupnom znanstvenom i stručnom programu, a sve je bilo i iscrpljujuće i dekoncentrirajuće. Navedeno svakako treba ozbiljno uzeti u obzir pri planiranju rasporeda sljedećeg kongresa. Mnoštvo tema, i još više pitanja koje su one potaknule, nedvojbeno svjedoči da postoji opravdana potreba za njihovim organiziranim predstavljanjem i raspravama o brojnim aspektima i problemima ruralnog turizma i njegovim posebnim oblicima, koji i na taj način potvrđuje da je "živ", aktualan, i da za njega postoji veliki interes.

Od ostalih "radnih" događanja na Kongresu treba izdvojiti debatni klub, na kojem su predstavnici turističkih seljačkih gospodarstava, poduzetnici i ostali dionici u ruralnom turizmu, kao i zainteresirani, iznijeli niz činjenica, problema i korisnih informacija, s ciljem njihovog promišljanja i rješavanja u daljnjem planskom razvoju ruralnog turizma u Hrvatskoj. Posebnu, pak, važnost imalo je organiziranje okruglog stola "Prema Strategiji razvoja ruralnog turizma", u organizaciji Ministarstva turizma Republike Hrvatske, na kojem su se mogli čuti zanimljivi prijedlozi, opaske, kritike, ali i problemi predstavnika turističkih seljačkih obiteljskih gospodarstava, kao i onih relevantnih institucija i pojedinaca, što sve čini odgovarajući temelj i poticaj za žurniju izradu "Strategije", koja se, kako je razvidno, sve više pokazuje nužnom.

Drugi hrvatski kongres o ruralnom turizmu završio je donošenjem zaključaka, među kojima se ističe važnost žurnog osnivanja Vladinog povjerenstva za ruralni turizam. Kako je navedeno u zaključcima, u "Strategiji razvoja hrvatskog turizma", koja će se uskoro početi pripremati, mora biti značajnije zastupljen ruralni turizam. Potrebno je izraditi dugoročne planove za razvoj ruralnog turizma i postići konsenzus svih relevantnih činitelja, prije svega resornih ministarstava. "Strategiju razvoja 
ruralnog turizma" nužno je uskladiti s nacionalnim, regionalnim i lokalnim strategijama, a ona se mora oslanjati i na izvore financiranja iz EU i drugih međunarodnih fondova. Također, sudionici Kongresa zaključili su da se ruralni turizam mora razvijati kao jedan od ključnih činitelja razvoja hrvatskih ruralnih područja, a time i jednakomjernog razvoja svih prostora Hrvatske. Takvom novom ponudom na turističkom tržištu stvara se i prepoznatljiva slika Hrvatske kao "lifestyle" odredišta. Aktivnosti i ciljevi "Strategije" trebaju biti usmjereni prema lokalnoj zajednici, razvijati regionalna turistička odredišta, te uvesti obveznu izobrazbu za sve koji se bave ruralnim turizmom. Na Kongresu je pokrenuta i nova akcija "Suncokret ruralnog turizma Hrvatske", kojom će se birati najbolji poduzetnici i proizvođači u ruralnom turizmu. Nagrade će se dijeliti u kategorijama: "Turistička seljačka gospodarstva", "Poduzetnici u ruralnom turizmu", "Ruralno-turistički projekti", "Ruralno-turističke manifestacije" i "Tradicijska ruralna gastronomija". Znanstvenim i stručnim temama te primjerima dobre prakse, kao i malim sajmom ruralnog turizma i drugim popratnim "popularnim" događanjima, predstavljeni su proizvodi i ponuda hrvatskog ruralnog prostora te su dane smjernice za njegov razvoj. Na Kongresu su se "čuli" znanost i struka, a posebno poduzetnici u ruralnom prostoru, kao što su turistička seljačka gospodarstva i ostali koji se bave proizvodnom i ugostiteljskom djelatnosti, prometom i uslugama, svi ujedinjeni u zajedničkom cilju - stvaranju ruralnog turističkog proizvoda. Drugi kongres svojevrsna je nadogradnja Prvome u strateškom pristupu, promjenama zakonske regulative te sagledavanju domaćih i stranih trendova i iskustava. U okviru ovoga Kongresa prezentirala se i hrvatska izvornost, kao i mogućnosti razvoja ruralnog prostora u cjelini s naglaskom na specifičnostima pojedinih regija na putu stvaranja brenda hrvatske ruralne turističke ponude i pojedinih destinacija. U cjelini, Kongres se može ocijeniti pozitivnom ocjenom, potvrdio se potrebnim i poticajnim i dao je relevantni prilog proučavanju ruralnog turizma u Hrvatskoj na svim razinama, te treba podržati održavanje sljedećeg, trećeg Kongresa, čiji domaćin će biti Osječko-baranjska županija.

\section{Damir Demonja}

